\title{
Lack of a lipoprotein-induced insulin resistance in hepatoma cells in culture
}

\author{
F. Rinninger ${ }^{1}$, B. Wolf ${ }^{2}$, H. U. Haering ${ }^{2}$ and W. Bachmann ${ }^{2}$ \\ ${ }^{1}$ Division of Endocrinology and Metabolism, Department of Medicine, M-013D, University of California, San Diego, \\ La Jolla, California, USA; ${ }^{2}$ Forschergruppe Diabetes, Munich, FRG
}

\begin{abstract}
Summary. A lipoprotein-induced resistance to the action of insulin has been postulated. To test this hypothesis, cultured ratderived hepatoma cells, designated $\mathrm{FAO}$, and human-derived hepatoma cells, designated HEP-G2, were incubated for $20 \mathrm{~h}$ in the presence or absence of lipoproteins; specific ${ }^{125} \mathrm{I}$-insulin receptor binding and labeled glucose incorporation into glycogen were then measured. Very low density lipoproteins $(\mathrm{d}<1.006 \mathrm{~g} / \mathrm{ml})$ in physiologic $(0.5 \mathrm{mg} / \mathrm{ml})$ or pathophysiologic $(5 \mathrm{mg} / \mathrm{ml})$ concentrations did not modify insulin receptor binding of FAO or HEP-G2 cells. This was true for very low density lipoproteins derived from normal human, diabetic human, and streptozotocin-diabetic rat plasma. Low density
\end{abstract}

lipoproteins $(\mathrm{d}=1.019-1.063 \mathrm{~g} / \mathrm{ml})$ isolated from normal human plasma similarly failed to modify insulin receptor binding. Concerning insulin action, the different very low density lipoprotein preparations did not modulate either basal or insulin-stimulated glucose incorporation into glycogen of the cells. Thus, very low density lipoproteins and low density lipoproteins did not induce insulin resistance in cultured hepatoma cells either at the insulin receptor level or at the post-receptor level.

Key words: Insulin resistance, lipoproteins, liver, insulin binding, insulin action, hepatoma cells.
Hyperlipoproteinaemias are frequent metabolic disturbances in patients with diabetes mellitus [1]. Several in vitro $[2,3]$ and in vivo [4-6] studies have led to the hypothesis that lipoproteins per se can modify insulin action at the cellular level, i.e. induce resistance to the action of the hormone.

Endogenous hypertriglyceridaemia (type IV) is frequently associated with insulin resistance [4-6]. Recently, decreased insulin receptor binding of monocytes and erythrocytes was demonstrated in such nonobese patients [4]. It was suggested that this might be directly due to elevated levels of very low density lipoproteins (VLDL) [4]. In fact, VLDL reduced insulin receptor binding of adipocytes and IM-9 lymphocytes in vitro [3]. In cultured aortic endothelial cells, malondialdehyde-altered low density lipoproteins (MDA-LDL) and beta-migrating VLDL (beta-VLDL) induced a post-receptor insulin resistance, but in this case there was no modification of insulin receptor binding induced by lipoproteins [2].

In view of these controversial results with extrahepatic cells, we asked if lipoproteins can induce insulin resistance in cells of hepatic origin. We used highly differentiated human- and rat-derived hepatoma cells in culture, designated HEP-G2 and FAO, which respre- sent well characterized models for metabolic studies [7-12]. Hyperlipoproteinaemia was simulated by the addition to the culture medium of VLDL and LDL derived from normal human, diabetic human and streptozotocin-diabetic rat plasma. Effects of these lipoproteins on insulin receptor binding and on the incorporation of glucose into glycogen were examined.

\section{Materials and methods}

D-[U- $\left.{ }^{14} \mathrm{C}\right]$-glucose, specific activity $275 \mathrm{mCi} / \mathrm{mmol}$ and $\mathrm{D}-\left[1-{ }^{3} \mathrm{H}\right]$-glucose, specific activity $5.7 \mathrm{Ci} / \mathrm{mmol}$ were from Amersham International, Amersham, UK. ${ }^{125}$ I-TYR-A14 monoiodoinsulin was a gift from Drs. Ronald Chance and Bruce Frank, Eli Lilly Corporation, Indianapolis, Ind, USA. Porcine monocomponent insulin, glycogen (from bovine liver, type IX), Hepes (N-2-Hydroxyethylpiperazine$\mathrm{N}^{\prime}$-2-ethanesulfonic acid) and streptozotocin were from Sigma, St.Louis, Mo, USA. Dulbecco's modified eagle medium (DME), "Medium 199", fetal calf serum, trypsin/EDTA (trypsin $0.5 \mathrm{~g} / 1$, $\mathrm{Na}_{2}$ EDTA $0.2 \mathrm{~g} / \mathrm{l}$ ), penicillin/streptomycin were from Gibco, Grand Island, NY, USA. Bovine serum albumin (fraction V) and enzymatic triglyceride kit were from Boehringer, Mannheim, FRG. Gentamicin was from Irvine Scientific, Santa Ana, Calif, USA. Male SpragueDawley rats were from Ivanovas, Kisslegg, FRG. Plastic culture dishes and flasks were from Falcon Plastics, Los Angeles, Calif, USA. All other chemicals and reagents were of analytical grade. 


\section{Cell culture}

HEP-G2 hepatoma cells, derived from a minimal deviation human hepatoma [9], were grown in Dulbecco's modified eagle medium (DME) supplemented with fetal bovine serum $(10 \% \mathrm{v} / \mathrm{v})$ and gentamicin $(50 \mathrm{mg} / \mathrm{l})$. FAO hepatoma cells, derived from a highly differentiated rat hepatoma [8], generously supplied by Dr. C. R. Kahn, Boston, Mass, USA, were cultured in "Medium 199" containing fetal bovine serum $(5 \% \mathrm{v} / \mathrm{v})$, penicillin $(100 \mathrm{U} / \mathrm{ml})$ and streptomycin $(100 \mathrm{mg} / 1)$. Both cell lines were routinely cultured in a humidified incubator at $37^{\circ} \mathrm{C}$ in an atmosphere of $\mathrm{CO}_{2}(5 \% \mathrm{v} / \mathrm{v})$ and air $(95 \% \mathrm{v} / \mathrm{v})$. The cells were split $1: 5$ every 7 days. For insulin binding and insulin action assays, cells were plated in $35-\mathrm{mm}$ diameter plastic culture dishes (400,000-500,000 cells/dish) and incubated in their respective media. After 3 days in culture, the medium was removed and fresh culture medium was added. In the case of the HEP-G2 cells, this medium contained human lipoprotein-deficient serum (LDS, 10\% v/v, $\mathrm{d}>1.21 \mathrm{~g} / \mathrm{ml}$ ) in place of fetal bovine serum; medium for the FAO cells contained $5 \%(\mathrm{v} / \mathrm{v})$ fetal bovine serum. To these media was added either the indicated lipoproteins or the corresponding volume of appropriate buffer (about $4 \% \mathrm{v} / \mathrm{v}$ ). The cells were then incubated for $20 \mathrm{~h}$ with or without lipoproteins. After culture, the cells were washed with phosphate-buffered saline (PBS, $\mathrm{pH} 7.4,4^{\circ} \mathrm{C}$ ).

\section{Lipoproteins}

Very low density lipoproteins (VLDL, $\mathrm{d}<1.006 \mathrm{~g} / \mathrm{ml}$ ) and low density lipoproteins $(\mathrm{LDL}, \mathrm{d}=1.019-1.063 \mathrm{~g} / \mathrm{ml}$ ) were isolated by sequential preparative ultracentrifugation $(2 \times 20 \mathrm{~h}, 50,000 \mathrm{rpm})$ in the presence of EDTA $(1 \mathrm{mg} / \mathrm{ml})$ [13]. Both fractions were washed by reflotation at the higher density limit to eliminate albumin contamination. Lipoprotein-deficient serum (LDS, $\mathrm{d}>1.21 \mathrm{~g} / \mathrm{ml}$ ) was derived from human plasma after adjusting the density to $1.21 \mathrm{~g} / \mathrm{ml}$. Densities were adjusted by the addition of $\mathrm{NaBr}$. Prior to their use, the lipoproteins and the lipoprotein-deficient serum were exhaustively dialyzed against phosphate-buffered saline $\left(\mathrm{pH} 7.4,4^{\circ} \mathrm{C}\right)$ containing EDTA $(1 \mathrm{mg} / \mathrm{ml})$. In some cases, the lipoproteins were dialyzed against saline $\left(\mathrm{NaCl} 154 \mathrm{mmol} / 1, \mathrm{pH} 7.4,4^{\circ} \mathrm{C}\right)$ containing glutathione $(0.2 \mathrm{mg} /$ $\mathrm{ml}$ ) instead of EDTA. Before use, the lipoproteins were sterile filtered $(0.44 \mu \mathrm{m})$.

Plasma for lipoprotein preparation was obtained from three sources: pooled human blood after an overnight fast; fasting, Type 2 (non-insulin-dependent) diabetic patients with moderate secondary hyperlipoproteinaemia (serum triglyceride $2-3 \mathrm{mg} / \mathrm{ml}$ ); and streptozotocin-diabetic rats. Diabetes was induced in these rats according to the procedure described in detail by Bar-On et al. [14]. Male Sprague-
Dawley rats were injected via the tail vein with streptozotocin $(45 \mathrm{mg} /$ $\mathrm{kg}$ body weight); all animals were killed 7 days after this injection by exsanguination from the abdominal aorta. Prior to killing, the animals were fasted for $6 \mathrm{~h}$. Mean blood glucose was $13.44 \mathrm{mmol} / \mathrm{l}$ at the time of killing, and mean serum triglyceride was $2.76 \mathrm{mg} / \mathrm{ml}$. It was shown by electrophoresis that the diabetic rat VLDL fraction was free of chylomicrons.

The triglyceride concentrations of the VLDL preparations and media were measured using a commercial enzymatic kit and are indicated in terms of $\mathrm{mg}$ triglyceride/ml. LDL protein content was determined after delipidation of lipoproteins with a mixture of $3: 1(\mathrm{v} / \mathrm{v})$ ethanol:diethylether. Protein was then determined by the Lowry method [15]. LDL concentrations are indicated as mg LDL protein/ $\mathrm{ml}$.

Electrophoretic mobilities of the lipoproteins were determined on agarose gels.

\section{Insulin binding}

For the determination of insulin receptor binding, cells were incubated in fresh Hanks Hepes buffer (Hepes $20 \mathrm{mmol} / 1, \mathrm{pH} 7.4,1.5 \mathrm{ml} /$ dish) containing albumin $(1 \mathrm{mg} / \mathrm{ml})$. This buffer additionally contained ${ }^{125} \mathrm{I}$-insulin (mono- ${ }^{125}$ I-[TYR-A14]-insulin, $0.1 \mu \mathrm{Ci} / \mathrm{dish}$, specific activity $200-300 \mu \mathrm{Ci} / \mu \mathrm{g}$ ) alone or together with the indicated concentrations of unlabeled insulin. Binding equilibrium was reached in both cell lines within $2 \mathrm{~h}$ at $20^{\circ} \mathrm{C}$. Nonspecific ${ }^{125} \mathrm{I}$-insulin binding was measured by incubating cells with labeled insulin $(0.1 \mu \mathrm{Ci} / \mathrm{dish})$ and an excess of unlabeled insulin $(1000 \mathrm{U} / 1)$. At the end of the incubation period, the medium was aspirated and the cell layer washed with phosphate-buffered saline $\left(\mathrm{pH} 7.4,4^{\circ} \mathrm{C}, 4 \times\right)$. Cells were then solubilized by the addition of $\mathrm{NaOH}$ solution $(0.2 \mathrm{~mol} / 1,2 \times 0.5 \mathrm{ml})$ and scraped off the plates with a rubber policeman. The radioactivity associated with the cells was measured in a gamma counter. An aliquot of the solubilized cells was used for protein determination according to the method described by Lowry et al. [15]. All binding data were corrected for non-specific insulin binding.

\section{Labeled glucose incorporation into glycogen}

The assay for insulin-stimulated incorporation of labeled glucose into glycogen was carried out as previously described [16] according to the method of Hofmann et al. [17]. FAO cells were incubated with culture medium $\left(37^{\circ} \mathrm{C}, \mathrm{pH} 7.4,1 \mathrm{mg} / \mathrm{ml}\right.$ albumin) containing $0.2 \mu \mathrm{Ci} \mathrm{D}-[\mathrm{U}$ $\left.{ }^{14} \mathrm{C}\right]$-glucose/dish (specific activity $275 \mathrm{mCi} / \mathrm{mmol}$ ) at a final glucose concentration of $2.5 \mathrm{mmol} / 1$. HEP-G2 cells were incubated in culture

Table 1. Effect of very low density lipoproteins on specific insulin binding of FAO hepatoma cells

\begin{tabular}{|c|c|c|c|c|}
\hline $\begin{array}{l}\text { Lipoprotein in the } \\
\text { culture medium } \\
\text { during } 20 \mathrm{~h}\end{array}$ & \multicolumn{4}{|c|}{ Insulin specific bound ( $\mu \mathrm{U} / \mathrm{mg}$ cell protein) } \\
\hline Human VLDL & & & & \\
\hline $\begin{array}{l}\text { Control } \\
\text { VLDL-TG }(5 \mathrm{mg} / \mathrm{ml})\end{array}$ & $\begin{array}{l}0.112 \pm 0.033 \\
0.108 \pm 0.040\end{array}$ & $\begin{array}{l}1.848 \pm 0.707 \\
1.848 \pm 0.814\end{array}$ & $\begin{array}{l}10.881 \pm 4.804 \\
12.420 \pm 4.779\end{array}$ & $\begin{array}{l}4 \\
4\end{array}$ \\
\hline $\begin{array}{l}\text { Rat diabetic VLDL } \\
\text { Control } \\
\text { VLDL-TG }(5 \mathrm{mg} / \mathrm{ml})\end{array}$ & $\begin{array}{l}0.219 \pm 0.040 \\
0.233 \pm 0.061\end{array}$ & $\begin{array}{l}3.111 \pm 0.621 \\
3.335 \pm 0.650\end{array}$ & $\begin{array}{l}18.837 \pm 4.080 \\
20.646 \pm 1.367\end{array}$ & $\begin{array}{l}3 \\
3\end{array}$ \\
\hline
\end{tabular}

FAO hepatoma cells were incubated during the last $20 \mathrm{~h}$ in culture in the absence (control) or the presence of the indicated level of VLDL. ${ }^{125} \mathrm{I}$-insulin binding alone or in the presence of the indicated concentrations of unlabeled insulin was measured as described under "Materials and Methods". ${ }^{125}$ I-insulin concentration was $4.44 \mathrm{mU} / 1$ for the experiments with human VLDL, $5.88 \mathrm{mU} / 1$ for those with human Type 2 diabetic VLDL and $6.08 \mathrm{mU} / 1$ for those with rat diabetic VLDL. Values represent mean $\pm S E M$. All determinations were performed in duplicate. $n=$ number of individual experiments. $p>0.05$ for all insulin concentrations in each experimental group 
medium $\left(37^{\circ} \mathrm{C}, \mathrm{pH} 7.4,1 \mathrm{mg} / \mathrm{ml}\right.$ albumin) containing $4 \mu \mathrm{Ci}$ D- $\left[1-{ }^{3} \mathrm{H}\right]-$ glucose/dish (specific activity $5.7 \mathrm{Ci} / \mathrm{mmol}$ ), at a final glucose concentration of $5.5 \mathrm{mmol} / \mathrm{l}$. Basal glycogen synthesis was measured in the absence of insulin and stimulated synthesis in the presence of the indicated insulin concentrations. After $2 \mathrm{~h}$ incubation at $37^{\circ} \mathrm{C}$, the incubation medium was removed and the cells were washed with phosphate-buffered saline $\left(\mathrm{pH} 7.4,4^{\circ} \mathrm{C}, 4 \times\right)$. Glycogen was extracted as previously described [16]. Blank values were obtained by parallel incubation of cells at a temperature of $2^{\circ} \mathrm{C}$ for $2 \mathrm{~h}$ with medium containing labeled glucose. The results were corrected for blank values and protein content.

\section{Statistical analysis}

The Student's t-test for paired observations was used for the evaluation of statistical differences. A value of $p<0.05$ was considered significant.

Table 2. Effect of very low density lipoproteins on basal and insulin stimulated glycogen synthesis in FAO hepatoma cells

\begin{tabular}{llll}
\hline $\begin{array}{l}\text { Lipoprotein in the } \\
\text { culture medium }\end{array}$ & \multicolumn{2}{l}{$\begin{array}{l}\text { Glucose incorporated into glycogen } \\
\text { (nmol glucose/mg cell protein per } 2 \mathrm{~h})\end{array}$} \\
\cline { 2 - 4 } & Basal & Insulin $(1000 \mathrm{mU} / \mathrm{l})$ & $n$ \\
\hline $\begin{array}{l}\text { Human VLDL } \\
\text { Control }\end{array}$ & $1.820 \pm 0.452$ & $3.971 \pm 0.382$ & 5 \\
$\quad$ VLDL-TG $(5 \mathrm{mg} / \mathrm{ml})$ & $1.609 \pm 0.396$ & $4.032 \pm 0.645$ & 5 \\
Human Type 2 diabetic & & & \\
VLDL & & & 4 \\
$\quad$ Control & $1.904 \pm 0.707$ & $3.493 \pm 1.491$ & 4 \\
VLDL-TG $(5 \mathrm{mg} / \mathrm{ml})$ & $1.920 \pm 0.611$ & $3.510 \pm 1.348$ & 4 \\
Rat diabetic VLDL & & & 3 \\
$\quad$ Control & $2.182 \pm 0.182$ & $3.923 \pm 0.483$ & 3 \\
VLDL-TG $(5 \mathrm{mg} / \mathrm{ml})$ & $2.117 \pm 0.207$ & $4.176 \pm 0.081$ & 3 \\
\hline
\end{tabular}

FAO hepatoma cells were incubated during the last $20 \mathrm{~h}$ in culture in the absence (control) or presence of the indicated VLDL. Basal and insulin-stimulated glucose incorporation into glycogen were then measured as described under "Materials and Methods". Values represent mean \pm SEM. All determinations were performed in triplicate. $n=$ number of separate experiments. $p>0.05$ for all values

\section{Results}

Rat-derived FAO hepatoma cells were cultured in the absence or presence of pathophysiologic VLDL concentrations $(5 \mathrm{mg} / \mathrm{ml})$ for $20 \mathrm{~h}$ prior to measurement of insulin binding and insulin action. In preliminary experiments (data not shown), the effect of insulin on labeled glucose incorporation into glycogen was very low when insulin was added to the preincubation media, suggesting the accumulation of an inhibiting factor. Therefore, the media were changed for the assays of insulin binding or action. VLDL was not included during these short term assays. VLDL derived from normal human plasma had no effect on ${ }^{125} \mathrm{I}$-insulin receptor binding compared to insulin binding to cells cultured in the absence of VLDL (Table 1). As parameter of insulin action in FAO hepatoma cells, insulin stimulation of labeled glucose incorporation into glycogen was measured. Insulin $(1000 \mathrm{mU} / 1)$ stimulated glucose incorporation into glycogen to $218 \%$ above the basal control (Table 2). Basal glucose incorporation into glycogen was not different in VLDL treated cells, compared to cells incubated without lipoproteins. Insulin stimulation of glycogen synthesis was not significantly different $(p>0.05)$ in FAO cells incubated in the presence of VLDL compared to cells incubated in the absence of VLDL (Table 2).

The lack of a lipoprotein effect on insulin binding and action might have been attributed to compositional differences between lipoproteins from normal and diabetic men and animals $[14,18,19]$. To address this possibility, the FAO cells were also cultured in the presence of VLDL $(5 \mathrm{mg} / \mathrm{ml})$ isolated from the plasma of Type 2 diabetic patients and streptozotocin-induced diabetic rats (Tables 1 and 2). However, these VLDL preparations again had no effect on insulin receptor binding

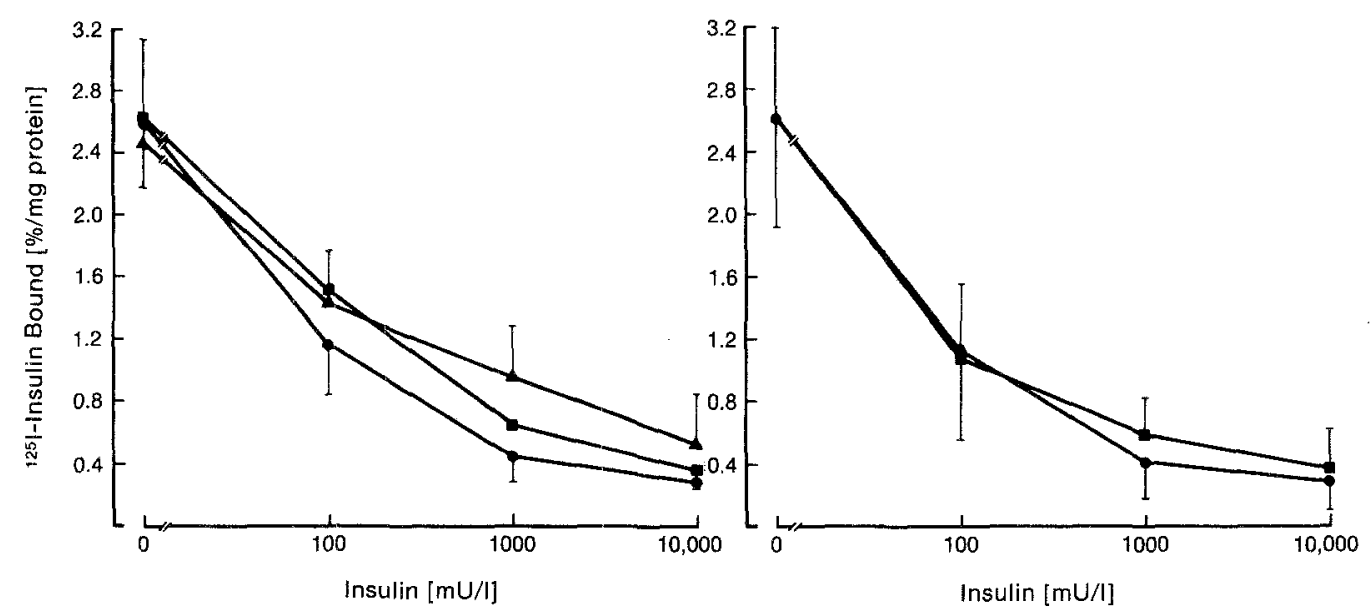

Fig. 1. Effect of very low-density lipoproteins (left) and low-density lipoproteins (right) on specific ${ }^{125}$ I-insulin receptor binding of HEP-G2 cells. Left: Cells were incubated for $20 \mathrm{~h}$ in the absence of VLDL (---) or in the presence of normal human VLDL at a concentration of $0.5 \mathrm{mg} / \mathrm{ml}$ ( - - $5 \mathrm{mg} / \mathrm{ml}$ ( as described in "Materials and methods". Values are mean \pm SEM of four individual experiments. All determinations were performed in duplicate. Bars illustrate SEM values at each point. Differences were not significant $(p>0.05)$ at any insulin concentration. Right: Cells were incubated for $20 \mathrm{~h}$ in the absence (---) or presence of normal human LDL ( was measured as described above. Values are mean \pm SEM of three individual experiments, with all determinations performed in duplicate. Differences were not statistically different $(p>0.05)$ at all insulin concentrations tested 


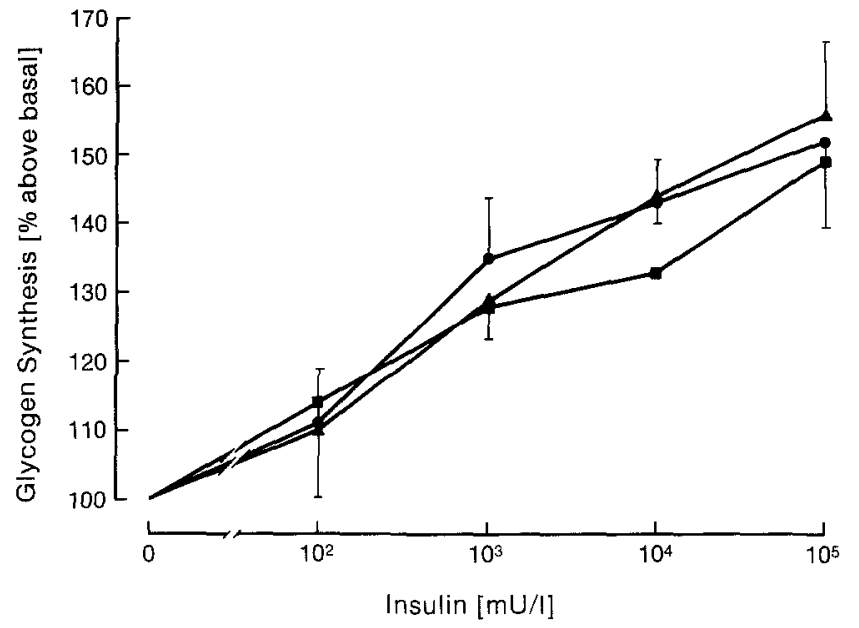

Fig.2. Influence of very low-density lipoproteins on glucose incorporation into glycogen of HEP-G2 cells. Cells were incubated for $20 \mathrm{~h}$ in the absence of lipoproteins (---.- ) or in the presence of normal human VLDL in a concentration of $0.5 \mathrm{mg} / \mathrm{ml}(\mathbf{- - - -})$ or $5 \mathrm{mg} / \mathrm{ml}$ ( $\Delta--\infty$ ). Basal and insulin-stimulated rates of labeled glucose incorporation into glycogen (insulin concentrations as indicated) were measured as described in "Materials and methods". Values are mean of 3 individual experiments. In 2 experiments the determinations were performed in triplicate, and in 1 experiment the determinations were performed in duplicate. SEM are shown for the control group and the cells incubated in the presence of VLDL $(5 \mathrm{mg} / \mathrm{ml})$. Differences were not significant $(p>0.05)$ for basal and all insulin-stimulated levels of glucose incorporation into glycogen. Basal glucose incorporation into glycogen $(=100 \%)$ was for cells incubated for $20 \mathrm{~h}$ in the absence of lipoproteins $4.72 \pm 0.41 \mathrm{nmol}$ glucose $\times \mathrm{mg}$ protein $(-1) \times 2 \mathrm{~h}(-1)$ incorporated into glycogen (mean \pm SEM); for cells incubated for $20 \mathrm{~h}$ in the presence of $0.5 \mathrm{mg} / \mathrm{ml} \mathrm{VLDL}$, it was $5.21 \pm 1.12$; for cells incubated in the presence of $5 \mathrm{mg} / \mathrm{ml}$ VLDL, $4.81 \pm 0.16$

(Table 1). Similarly, basal and insulin-stimulated incorporation of labeled glucose into glycogen in FAO cells was not significantly modified by VLDL isolated from diabetic rat and diabetic human plasma (Table 2).

As a model for human hepatocytes, highly differentiated HEP-G2 hepatoma cells were used [9]. Figure 1 shows cellular ${ }^{125} \mathrm{I}$-insulin binding and its displacement by unlabeled insulin. Insulin binding data were not different whether the cells were cultured in the absence of VLDL (control), in the presence of physiologic $(0.5 \mathrm{mg}$ / $\mathrm{ml})$ or pathophysiologic $(5 \mathrm{mg} / \mathrm{ml})$ concentrations of normal human VLDL (Fig.1, left). Under identical incubation conditions with VLDL, insulin action was measured as shown in Figure 2. Insulin (100-100,000 mU/1) stimulated ${ }^{3} \mathrm{H}$-glucose incorporation into glycogen in a dose-dependent manner. Basal glucose incorporation was not modified when the HEPG2 cells were incubated with normal human VLDL. In agreement with data for the rat cell line, insulin stimulation of labeled glucose incorporation into glycogen was not significantly different in HEP-G2 cells incubated in the absence of VLDL or incubated in the presence of physiologic $(0.5 \mathrm{mg} / \mathrm{ml})$ or pathophysiologic $(5 \mathrm{mg} /$ ml) VLDL levels (Fig. 2).

LDL levels are frequently elevated in diabetic patients [20]. Therefore, their effect on insulin receptor binding in HEP-G2 cells was examined. The LDL con- centration used $(0.5 \mathrm{mg} / \mathrm{ml}$ protein, approximately $1 \mathrm{mg} / \mathrm{ml}$ cholesterol) was within the physiologic range, and sufficient to downregulate high affinity LDL-receptor activity [7]. As shown in Figure 1 (right), LDL did not change ${ }^{125}$ I-insulin receptor binding compared to that in cells incubated in the presence of lipoprotein-deficient serum (LDS) alone.

The lack of a lipoprotein-induced insulin resistance might have been the consequence of lipoprotein catabolism by the cells during the $20 \mathrm{~h}$ of incubation with the lipoproteins. Therefore, VLDL-triglyceride and LDLcholesterol concentrations and electrophoretic mobility of the lipoproteins on agarose gels were determined after the $20 \mathrm{~h}$ incubation. The measured parameters were compared to those of lipoproteins not incubated with cells (data not shown). VLDL-triglyceride concentrations $(0.5$ and $5 \mathrm{mg} / \mathrm{ml})$ and LDL-cholesterol concentration were not measurably different from original levels after $20 \mathrm{~h}$ of incubation with cells. Similarly, electrophoretic mobility of VLDL $(0.5$ and $5 \mathrm{mg} / \mathrm{ml})$ and LDL $(0.5 \mathrm{mg} / \mathrm{ml})$ on agarose gels was not significantly different after $20 \mathrm{~h}$ of incubation with cells when compared to the mobility of lipoproteins not incubated with hepatoma cells.

To examine the possibility of a toxic effect of the lipoproteins on the cells, cellular protein content and viability were determined. Cellular protein content of HEP-G2 cells and FAO cells after incubation for $20 \mathrm{~h}$ in the presence or absence of lipoproteins was similar, regardless of the presence of VLDL $(0.5$ or $5 \mathrm{mg} / \mathrm{ml})$ or LDL $(0.5 \mathrm{mg} / \mathrm{ml})$ during the incubation (data not shown). Viability of the cells as determined by trypan blue exclusion under the phase contrast microscope was identical in the cells incubated for $20 \mathrm{~h}$ with or without lipoproteins.

\section{Discussion}

In this study with hepatoma cells, VLDL and LDL did not modify insulin receptor binding. Similarly, Berliner et al. [2] observed that neither beta-migrating very low density lipoproteins (beta-VLDL) nor malondialdehyde-altered LDL (MDA-LDL) had any effect on insulin receptor binding in aortic endothelial cells in culture. In contrast to these data, Steiner et al. [3] observed reduced insulin receptor binding in rat adipocytes in suspension and cultured IM-9 lymphocytes of human origin incubated with VLDL. Taken together, these results suggest that triglyceride-rich VLDL can modify insulin receptor binding in extrahepatic tissues [3] but not in cells of hepatic origin. However, in contrast to the triglyceride-rich VLDL, cholesterol-rich lipoproteins like LDL, beta-VLDL and MDA-LDL do not modulate insulin receptor-interaction in the cells studied [2]. The possibility that only primary cells are sensitive to lipoprotein-induced modulation of cellular insulin action is argued against by the reduced insulin receptor binding 
in the lymphocyte cell line after culture in the presence of VLDL [3].

In this study, VLDL did not modify insulin action. In the investigation with adipocytes and lymphocytes, no biologic effects of insulin were measured [3]. Thus, the metabolic significance of reduced insulin receptor binding in that study [3] is not clear. In contrast, in aortic endothelial cells [2] beta-VLDL and MDA-LDL induced a post-receptor insulin resistance, as measured by amino acid transport; such an effect could not be induced by LDL in the same cells [2]. Beta-VLDL and MDA-LDL were taken up by the aortic cells and increased their cholesterol content $[2,21]$ while LDL and VLDL do not comparably alter the cellular cholesterol content [21, 22]. This suggests that an increased cellular cholesterol could possibly induce resistance to the action of insulin and explain our lack of a lipoprotein effect [23]. Alternative explanations for the differences may lie in a tissue specificity between hepatic and extrahepatic cells. Hepatic cells are able to process lipids in ways that other cells cannot, e.g. in bile production, and that might explain the apparent discrepancy. It is also possible that amino acid transport and glucose incorporation into glycogen have a different susceptibility to a lipoprotein modification, thus explaining the differences in results.

The present in vitro studies should not be considered to exclude the possibility that in patients with diabetes mellitus or endogenous hypertriglyceridaemia, lipoproteins could indeed induce insulin resistance. For instance "remnant" particles derived from VLDL and chylomicrons $[19,24]$ might be taken up avidly enough by the liver [25] to affect insulin action, even though VLDL did not have this effect in vitro.

In summary, our results do not support the hypothesis of a VLDL-induced resistance to the action of insulin either at the insulin receptor or at the post-receptor level.

Acknowledgements. We thank Daniel Steinberg, M.D., Ph.D., and Ray C. Pittman, Ph. D. for stimulating discussions and critical review of this manuscript.

\section{References}

1. Reaven GM, Greenfield MS (1981) Diabetic hypertriglyceridemia: evidence for three clinical syndromes. Diabetes 30 (Suppl 2): 66-75

2. Berliner JA, Frank JL, Karasic D, Capdeville M (1984) Lipoprotein-induced insulin resistance in aortic endothelium. Diabetes 33: 1039-1044

3. Steiner G, Vranic M (1982) Hyperinsulinemia and hypertriglyceridemia, a vicious cycle with atherogenic potential. Int J Obesity 6 (Suppl 1): 117-124

4. Bieger WP, Michel G, Barwich D, Biehl K, Wirth A (1984) Diminished insulin receptors on monocytes and erythrocytes in hypertriglyceridemia. Metabolism 33:982-987

5. Reaven GM, Mejean L, Villaume C, Drouin P, Debry G (1983) Plasma glucose and insulin responses to oral glucose in nonobese subjects and patients with endogenous hypertriglyceridemia. Metabolism 32: $447-450$
6. Steiner G, Morita S, Vranic M (1980) Resistance to Insulin but not to glucagon in lean human hypertriglyceridemics. Diabetes 29: $899-905$

7. Dashti N, Wolfbauer G, Koren E, Knowles B, Alaupovic P (1984) Catabolism of human low density lipoproteins by human hepatoma cell line Hep G2. Biochim Biophys Acta 794: 373-384

8. Crettaz M, Kahn CR (1983) Analysis of insulin action using differentiated and dedifferentiated hepatoma cells. Endocrinology 113: 1201-1209

9. Knowles BB, Howe CC, Aden DP (1980) Human hepatocellular carcinoma cell lines secrete the major plasma proteins and hepatitis B surface antigen. Science 209: 497-499

10. Maron R, Kahn CR, Jacobs S, Fujita-Yamaguchi Y (1984) Visualization of the insulin receptor by immunoblotting. Diabetes 33 : 923-928

11. Podskalny JM, Takeda S, Silverman R, Tran D, Carpentier JL, Orci L, Gorden P (1985) Insulin receptors and bioresponses in a human liver cell line (Hep G-2). Eur J Biochem 150: 401-407

12. Verspohl EJ, Roth RA, Vigneri R, Goldfine ID (1984) Dual regulation of glycogen metabolism by insulin and insulin-like growth factors in human hepatoma cells (HEP-G2). J Clin Invest 74 : 1436-1443

13. Havel RJ, Eder HA, Bragdon JH (1955) The distribution and chemical composition of ultracentrifugically separated lipoproteins in human serum. J Clin Invest 34: 1345-1353

14. Bar-On H, Roheim PS, Eder HA (1976) Serum lipoproteins and apolipoproteins in rats with streptozotocin-induced diabetes. J Clin Invest 57: 714-721

15. Lowry OH, Rosebrough NJ, Farr AL, Randall RL (1951) Protein measurement with the fohn phenol reagent. J Biol Chem 193: 265-275

16. Rinninger F, Kirsch D, Haering HU, Kemmler W (1984) Extrapancreatic action of the sulphonylurea gliquidone: post-receptor effect on insulin-stimulated glycogen synthesis in rat hepatocytes in primary culture. Diabetologia 26: 462-465

17. Hofmann C, Marsh JW, Miller B, Steiner DF (1980) Cultured hepatoma cells as a model for studying insulin processing and biologic responsiveness. Diabetes 29: 865-874

18. Gabor J, Spain M, Kalant N (1980) Composition of serum very low density and high density lipoproteins in diabetes. Clinical Chemistry 26: 1261-1265

19. Weisweiler P, Drosner M, Schwandt P (1982) Dietary effects on very low density lipoproteins in type II (non-insulin-dependent) diabetes mellitus. Diabetologia 23: 101-123

20. Sosenko JM, Breslow JL, Miettinen OS, Gabbay KH (1980) A prospective study of young insulin-dependent diabetic patients. $\mathrm{N}$ Engl J Med 302: 650-654

21. Baker DP, Van Lenten BJ, Fogelman AM, Edwards PA, Kean C, Berliner JA (1984) LDL, Scavenger and beta-VLDL receptors on aortic endothelial cells. Arteriosclerosis 4: 248-255

22. Reardon MF, Fidge NH, Nestel PJ (1978) Catabolism of very low density lipoprotein $B$ apoprotein in man. J Clin Invest 61: $850-860$

23. Karnovsky MJ, Kleinfeld AM, Hoover RL, Klausner RD (1982) The concept of lipid domains in membranes. J Cell Biol 94: 1-6

24. Lisch HJ, Sailer S (1981) Lipoprotein patterns in diet, sulphonylurea and insulin treated diabetics. Diabetologia 20:188-122

25. Brown MS, Goldstein JL (1986) A receptor mediated pathway for cholesterol homeostasis. Science 232: $34-47$

Received: 6 December 1985

and in revised form: 21 May 1986

\section{Dr. Franz Rinninger}

Department of Medicine M-013D

Division of Endocrinology and Metabolism

University of California, San Diego

La Jolla, CA 92093, USA 